\title{
EFFECT OF PHOTOPERIODS AND SEX RATIO ON PRODUCTIVE AND REPRODUCTIVE PERFORMANCE OF JAPANESE QUAIL
}

\author{
H.A. Khalil, A.M. Hanafy, M. Roshdy and M.E. Mady \\ Animal Production Department, Faculty of Agriculture, Suez Canal University, \\ Ismailia, Egypt
}

SUMMARY

The aim of this experiment was to study the effect of photoperiods and sex ratio and their interaction on productive, reproductive performance and some blood parameters of laying Japanese quail. The $4 \times 4$ factorial treatment design included four photoperiods $(12,14,16$ and $18 \mathrm{hr} / \mathrm{d})$ and four sex ratios $(1: 2,1: 4,1: 6$ and 1:8, male: female, respectively). A total of 920 birds at 6 weeks was individually weighed and randomly divided into 16 experimental groups. Each group was randomly assigned into 2 replicates. Data were collected on body weight, egg production, fertility, hatchability, embryonic mortality, egg quality traits, cloacal gland area, plumage condition and mortality rate until $18 \mathrm{wks}$ of age. Calcium, inorganic phosphorus and iron ions were determined in blood plasma. Results showed significant $(P<0.05)$ differences among treatments and their interactions in most studied traits. Final body weight of males kept under $12 \mathrm{hr} \mathrm{L/d} \mathrm{had} \mathrm{the} \mathrm{lightest} \mathrm{value}$ compared with all other photoperiods irrespective of sex ratio, also females kept under 1:8 sex ratio had the heaviest value compared with all other ratios irrespective of photoperiods. Birds kept under $16 \mathrm{hr} L / d$ had the highest laying intensity at sex ratio 1:4. The maximum values of fertility percent were obtained in eggs laid from quail kept in $14 \mathrm{hr}$ L/d at sex ratio $1: 2$ and $16 \mathrm{hr}$ L/d at sex ratio 1:4. Hatchability percent increased with increasing photoperiods, the highest value was obtained in eggs laid from birds kept in $18 \mathrm{~L} / \mathrm{d}$ followed by $16 \mathrm{hr} \mathrm{L/d}$. Yolk index increased but internal quality decreased with increasing photoperiods. Moreover, the highest score of plumage condition was obtained from birds kept under 16hr L/d at sex ratio 1:2. Cloacal gland area tended to increase with increasing photoperiods, but it decrease with increasing in sex ratio. On the other hand, plasma concentration of calcium and inorganic phosphorus increased with increasing in photoperiods, but iron was fluctuated among different photoperiods irrespective of sex ratio. The lowest mortality rates were recorded in both birds kept under $16 \mathrm{hr} L / d$ and sex ratio 1:8.

From this experiment, it could be concluded that, photoperiods $16 \mathrm{hr} \mathrm{L/d}$ and sex ratio 1:4 were significantly better in most studied traits compared with other experimental groups. The best interaction between photoperiods and sex ratio was obtained in group received $16 \mathrm{hr} \mathrm{L} / \mathrm{d}$ at 1:4 sex ratio to increase Japanese quail breeder's performance under commercial production.

Keywords: Japanese quail, photoperiod, sex ratio, performance, calcium, inorganic phosphorus

Issued by The Egyptian Society of Animal Production 


\section{INTRODUCTION}

Light is one environmental variable principally affecting certain activities associated with productive and reproductive cycles in birds (Farner, 1964). The influence of photoperiodism on gonadal activity, sexual maturity, feed consumption, weight gains and egg production in Japanese quail were investigated by many workers (Chaturvedi et al., 1991; Tsuyoshi and Wada, 1992; Wada, 1993; Boon et al., 2000, Khalil, 2004, El-Nagar et al., 2007, Khalil et al., 2006 and 2008). Photoperiod play an important role in development of gonads in both male and female quails, the role of photoperiod on the hypothalamus area through the eyes and extra-retinal photoreceptors. Consequently hypothalamus will secret gonadotropinreleasing hormone $(\mathrm{GnRH})$. In males, LH controls the production of the major sex steroid (testosterone) secreted by leydig cells in the testes. In females, the secretion of LH and FSH control the secretion of estrogen, which necessary for yolk precursor lipoprotein secretion by the liver and oviduct and follicle development. Gonadotropin-releasing hormones stimulate gonadal development, eventually resulting in onset of lay, day length has a major effect on protein synthesis rates (Bacon et al., 1980; Dunn and Sharp, 1990 and Lewis et al., 1999). On the other hand, the effect of sex ratio on performance of poultry was investigated by many investigations (Bates et al., 1987; Deeming and Wadland, 2002; Çetin, 2002 and ElFiky et al., 2006). In relation to Japanese quail, effect of sex ratio and interaction between sex ratio and photoperiods are poorly documented. Therefore, the objective of this research was to investigate the effect of different photoperiods $(12,14,16$ and $18 \mathrm{hr} /$ day) and different sex ratios (1:2, 1:4, 1:6 and 1:8, male:female, respectively) and their interactions on performance of laying Japanese quail.

\section{MATERIALS AND METHODS}

\section{Birds and husbandry:}

This experiment was carried out at the Poultry Farm, Department of Animal Production, Faculty of Agriculture, Suez Canal University, Ismailia, Egypt during winter season. The quails used in this experiment were kept under normal brooding conditions in brooding floor pens until they were 6 weeks of age under continuous light and with a gradual decrease in room temperature from $37^{\circ} \mathrm{C}$ at hatching to $25^{\circ} \mathrm{C}$ at 6 weeks of age. At 6 weeks of age, 920 birds were individually weighed and randomly distributed into four equal experimental group in four rooms according to lighting program. The $1^{\text {st }}$ room, birds were kept under $12 \mathrm{hr} \mathrm{L} / \mathrm{day}$. The $2^{\text {nd }}$ room, birds were kept under $14 \mathrm{hr} \mathrm{L} /$ day. The $3^{\text {rd }}$ room, birds were kept under $16 \mathrm{hr} \mathrm{L} /$ day. The $4^{\text {th }}$ room, birds were kept under $18 \mathrm{hr}$ L/day. Natural day light $10-11 \mathrm{hr} /$ day was used and completed with artificial tungsten light for each treatments. The light intensity ranged from 20-35 lux at the head of the birds as measured by luxmeter. In each room, birds were randomly distributed into four experimental groups according to sex ratio. The $1^{\text {st }}$ group, sex ratio was 1:2 (20 males:40 females). The $2^{\text {nd }}$ group, sex ratio was 1:4 (12 males:48 females). The $3^{\text {rd }}$ group, sex ratio was 1:6 (8 males:48 females). The $4^{\text {th }}$ group, sex ratio was 1:8 (6 males:48 females). Each group was randomly assigned into two replicates, birds were kept in floor pens $(100 \times 80 \times 60 \mathrm{~cm})$. Japanese quails were fed a conventional corn and soybean meal basal diet, formulated to meet all the nutritional requirements of laying quail according to 
specifications of the National Research Council (1994). The ration contained $20 \% \mathrm{CP}$ and $3000 \mathrm{Kcl}(\mathrm{ME}) / \mathrm{Kg}$. Both feed and water were provided ad libitum in all experimental groups.

\section{Studied traits:}

The birds were individually weighed at the start of experiment (6 wks) and 18 weeks of age. Egg number, egg weight $(\mathrm{g})$ and egg mass $(\mathrm{g})$ were recorded up to 18 weeks age. Fertility, hatchability and embryonic mortality were calculated as average during the experimental period $(8,10,12,14,16$ and 18 weeks of age). Egg shape index, internal quality unit, yolk shape index and shell thickness were calculated according to Sharp, (1929); Ivar and Jan (1968); Kondaiah et al. (1983) for two consecutive days at 14 and 18 weeks. Plumage scores were measured at 8,10, 14 and 18 weeks of age. Three areas of the body were measured (head, neck and back) using a scale from 1 (completely feathered) to 5 (featherless). The sum of the values for all three areas was calculated for each bird, with values ranging from 3(completely feathered) to 15 (featherless) according to Gerken (1991). The area of cloacal gland $\left(\mathrm{mm}^{2}\right)$ of males was measured using calipers at 8, 10, 14 and 18 weeks of age according to Siopes and Wilson (1975). At the end of experiment, 64 birds from all groups ( 32 males and 32 females) were slaughtered by slitting the jugular vein. Blood samples were collected in heparinized tubes. Plasma calcium, inorganic phosphorus and iron ions were measured calorimetrically using commercial kits from ELITech Company, France.

\section{Statistical Analysis:}

Data were analyzed using the General Linear Model (GLM) procedure of SAS (SAS., 1998). Least Square Means (LSM) were calculated and Least Square Differences (LSD) between means were tested.

\section{RESULTS AND DISCUSSION}

\section{Body weight:}

Results indicate that initial body weight (6 weeks old) did not differ significantly among the treatment groups (Table 1), indicating the complete randomized distribution of birds into the experimental groups. On the other hand, at the end of experiment, significant differences $(\mathrm{P}<0.05)$ were found among photoperiods for males and among sex ratio for females body weight. Males body weight tended to increase with increasing photoperiods, the heaviest value was recorded in males kept under $18 \mathrm{hr} \mathrm{L/d}$, while the lightest value was recorded in males kept under $12 \mathrm{hr} \mathrm{L} / \mathrm{d}$. In this respect, female subjected to sex ration 1:8 had significantly $(\mathrm{P}<0.05)$ heavier body weight compared with other groups.

These results are in agreement with other findings by Boon et al. (2000); AbouKaseem (2006) and Khalil et al. (2006) who reported that Japanese quail were kept under long day photoperiods had significantly heavier body weight than others which kept under short day photoperiods. These results indicated that, increasing in photoperiods play an important role in physiological process of birds such as, increase metabolic hormones which play an important role in increasing body weight (Boon et al., 2000). Also, increasing in photoperiod caused increase in period of feeding and food consumption (Lewis et al., 1996). 
Table 1. Body weight (g) of male and female quails at different ages as affected by photoperiods and sex ratio

\begin{tabular}{|c|c|c|c|c|}
\hline \multirow{2}{*}{\multicolumn{2}{|c|}{ Main effect }} & \multicolumn{3}{|c|}{ Age (wks) } \\
\hline & & & 6 & 18 \\
\hline \multirow{11}{*}{ Male } & \multirow{4}{*}{$\begin{array}{l}\text { Photoperiods } \\
\text { (P) }\end{array}$} & 12 & $212.51 \pm 5.45$ & $230.84 \pm 6.93^{b}$ \\
\hline & & 14 & $215.40 \pm 5.26$ & $245.27 \pm 6.93^{\mathrm{a}}$ \\
\hline & & 16 & $210.90 \pm 5.66$ & $251.35 \pm 6.93^{\mathrm{a}}$ \\
\hline & & 18 & $217.58 \pm 5.46$ & $258.22 \pm 6.93^{\mathrm{a}}$ \\
\hline & \multicolumn{2}{|c|}{ Significance of effect ${ }^{1}$} & NS & $*$ \\
\hline & \multirow{4}{*}{$\begin{array}{c}\text { Sex ratio } \\
\text { (SR) }\end{array}$} & $1: 2$ & $213.35 \pm 4.74$ & $245.94 \pm 5.14$ \\
\hline & & $1: 4$ & $220.25 \pm 5.64$ & $240.45 \pm 6.50$ \\
\hline & & $1: 6$ & $218.75 \pm 5.67$ & $249.38 \pm 7.27$ \\
\hline & & $1: 8$ & $216.84 \pm 5.95$ & $249.92 \pm 8.40$ \\
\hline & \multicolumn{2}{|c|}{ Significance of effect } & NS & NS \\
\hline & \multicolumn{2}{|c|}{ Ineraction $(\mathrm{P} * \mathrm{SR})$} & NS & NS \\
\hline \multirow{11}{*}{ Female } & \multirow{4}{*}{$\begin{array}{l}\text { Photoperiods } \\
\text { (P) }\end{array}$} & 12 & $238.25 \pm 2.63$ & $306.52 \pm 3.25$ \\
\hline & & 14 & $241.51 \pm 2.53$ & $302.06 \pm 3.23$ \\
\hline & & 16 & $239.71 \pm 2.63$ & $306.26 \pm 3.23$ \\
\hline & & 18 & $242.42 \pm 2.65$ & $303.49 \pm 3.25$ \\
\hline & \multicolumn{2}{|c|}{ Significance of effect } & $\mathrm{NS}$ & $\mathrm{NS}$ \\
\hline & \multirow{4}{*}{$\begin{array}{l}\text { Sex ratio } \\
\text { (SR) }\end{array}$} & $1: 2$ & $238.23 \pm 2.97$ & $302.36 \pm 3.63^{b}$ \\
\hline & & $1: 4$ & $243.58 \pm 2.25$ & $303.92 \pm 3.27^{\mathrm{b}}$ \\
\hline & & $1: 6$ & $242.08 \pm 2.62$ & $297.87 \pm 3.03^{b}$ \\
\hline & & $1: 8$ & $246.48 \pm 2.82$ & $314.18 \pm 2.98^{\mathrm{a}}$ \\
\hline & \multicolumn{2}{|c|}{ Significance of effect } & NS & $*$ \\
\hline & \multicolumn{2}{|c|}{ Ineraction $(\mathrm{P} * \mathrm{SR})$} & NS & NS \\
\hline
\end{tabular}

$1 * \mathrm{P}<0.05 ; * * \mathrm{P}<0.01 ; * * * \mathrm{P}<0.001$

a,b c, Means within a column in each factor with no common superscript are significantly different $(\mathrm{P}<0.05)$.

Egg production parameters:

High significant differences $(\mathrm{P}<0.01)$ were found among photoperiods, sex ratio in all egg production parameters, but the interactions between the two factors were significant $(\mathrm{P}<0.01)$ only in laying rate and egg weight traits (Table 2). Birds kept under $16 \mathrm{hr} \mathrm{L/d} \mathrm{had} \mathrm{the} \mathrm{highest} \mathrm{laying} \mathrm{intensity} \mathrm{at} \mathrm{sex} \mathrm{ratio} 1: 4$, but the lowest value was obtained from birds kept under $12 \mathrm{hr} \mathrm{L} / \mathrm{d}$ at sex ratio 1:6. Higher egg weight was obtained from birds kept under $14 \mathrm{hr} \mathrm{L/d}$ at sex ratio 1:4, but the lightest egg weight was obtained from birds kept under $12 \mathrm{hr} \mathrm{L} / \mathrm{d}$ at sex ratio 1:6. On the other hand, the lower values of egg number and egg mass/hen were obtained from birds kept under $12 \mathrm{hr} \mathrm{L} / \mathrm{d}$ as compared with other three photoperiods. Also, birds subjected to sex ratio 1:6 had the lower values as compared with other sex ratios.

The present results are in agreement with those obtained by Sakurai (1983); Prabakaran et al. (1991b); El-Matary (1994); Ahmed et al. (2000); Khalil (2004); Khalil et al. (2006); El-Nagar et al. (2007) who reported that Japanese quail females maintained under light period of 14 or $16 \mathrm{hr} /$ day had significantly $(\mathrm{P}<0.05)$ higher egg 
number, egg weight and egg mass compared with others maintained under light period of 10 or $12 \mathrm{hr} /$ day.

Table 2. Egg production parameters as affected by photoperiods and sex ratio from 6 to 18 weeks of age

\begin{tabular}{|c|c|c|c|c|c|}
\hline \multirow{2}{*}{\multicolumn{2}{|c|}{ Main effect }} & \multicolumn{4}{|c|}{ Traits } \\
\hline & & $\begin{array}{c}\text { Laying } \\
\text { rate }\end{array}$ & $\begin{array}{l}\text { egg umber } \\
\text { / hen }\end{array}$ & $\begin{array}{l}\text { egg weight } \\
\text { / hen }\end{array}$ & $\begin{array}{l}\text { Egg mass } \\
/ \text { hen }\end{array}$ \\
\hline \multirow{4}{*}{$\begin{array}{c}\text { Photoperiods } \\
\text { (P) }\end{array}$} & 12 & $48.18 \pm 0.67^{\mathrm{c}}$ & $40.50 \pm 1.64^{b}$ & $12.50 \pm 0.13^{b}$ & $511.25 \pm 22.72^{b}$ \\
\hline & 14 & $63.39 \pm 0.67^{\mathrm{b}}$ & $53.25 \pm 1.64^{\mathrm{a}}$ & $13.54 \pm 0.13^{\mathrm{a}}$ & $726.75 \pm 22.72^{\mathrm{a}}$ \\
\hline & 16 & $67.43 \pm 0.67^{\mathrm{a}}$ & $57.00 \pm 1.64^{\mathrm{a}}$ & $13.29 \pm 0.13^{\mathrm{a}}$ & $755.43 \pm 22.72^{\mathrm{a}}$ \\
\hline & 18 & $63.86 \pm 0.67^{\mathrm{b}}$ & $54.00 \pm 1.64^{\mathrm{a}}$ & $13.29 \pm 0.13^{\mathrm{a}}$ & $713.96 \pm 22.72^{\mathrm{a}}$ \\
\hline \multicolumn{2}{|c|}{ Significance of effect ${ }^{1}$} & $* * *$ & $* * *$ & $* * *$ & $* * *$ \\
\hline \multirow{4}{*}{$\begin{array}{l}\text { Sex ratio } \\
\text { (SR) }\end{array}$} & $1: 2$ & $64.00 \pm 0.64^{\mathrm{a}}$ & $54.00 \pm 1.64^{\mathrm{a}}$ & $13.07 \pm 0.13^{b}$ & $708.57 \pm 22.72^{\mathrm{a}}$ \\
\hline & $1: 4$ & $64.46 \pm 0.67^{\mathrm{a}}$ & $54.50 \pm 1.64^{\mathrm{a}}$ & $13.11 \pm 0.13^{\mathrm{b}}$ & $715.18 \pm 22.72^{\mathrm{a}}$ \\
\hline & $1: 6$ & $54.29 \pm 0.64^{\mathrm{c}}$ & $45.75 \pm 1.64^{\mathrm{c}}$ & $12.82 \pm 0.13^{\mathrm{b}}$ & $585.61 \pm 22.72^{b}$ \\
\hline & $1: 8$ & $60.11 \pm 0.64^{b}$ & $50.50 \pm 1.64^{b}$ & $13.61 \pm 0.13^{\mathrm{a}}$ & $688.04 \pm 22.72^{\mathrm{a}}$ \\
\hline \multicolumn{2}{|c|}{ Significance of effect } & $* * *$ & $* * *$ & $* * *$ & $* * *$ \\
\hline \multicolumn{2}{|c|}{ Interaction (PxSR) } & $* * *$ & NS & $* * *$ & NS \\
\hline
\end{tabular}

These results indicated that, increasing in photoperiods up to $16 \mathrm{hr} /$ day play an important role in physiological process of birds such as, increase secretion of metabolic hormones (T3, T4 and insulin), reproductive hormones (FSH, LH, estrogen and progesterone). All these hormones shared in development and enhancing productive functions (Wada, 1993 and Boon et al., 2000).

Effect of sex ratio on egg production traits irrespective of photoperiods, show that decreasing sex ratio $(1: 6$ or $1: 8)$ resulted in decreasing laying rate compared to higher sex ratio $(1: 2$ or $1: 4)$. These results are in agreement with other findings by Çetin (2002) who found that sex ratio (1:4) lead to increase in laying rate/hen compared to sex ratio 1:5. Moreover, Deeming and Wadland (2002) found that egg production was significantly higher in Pheasant under sex ratio 1:8 than 1:12. Conversely, Bates et al. (1987) reported that when the sex ratio decreased from 1:12 to 1:18 egg production of Pheasants was increased.

\section{Fertility, hatchability and embryonic mortality:}

Results showed significant $(\mathrm{P}<0.01)$ differences among photoperiods, sex ratio and their interactions in fertility percent during the entire study period (Table 3 ). The maximum values of fertility percent were obtained from eggs laid under $14 \mathrm{hr} \mathrm{L} / \mathrm{d}$ at sex ratio $1: 2$ followed by $16 \mathrm{hr} \mathrm{L} / \mathrm{d}$ at sex ratio $1: 4$. The minimum value was obtained in quail eggs laid at $18 \mathrm{hr} \mathrm{L} / \mathrm{d}$ at sex ratio 1:8. On the other hand, there are significant $(\mathrm{P}<0.05)$ differences only between photoperiods on each of hatchability and total dead embryos percent. Hatchability percentages were increased with increasing photoperiods. The highest hatchability was obtained under $18 \mathrm{~L} / \mathrm{d}$ followed by $16 \mathrm{hr}$ 
$\mathrm{L} / \mathrm{d}$ and the lowest was obtained under $14 \mathrm{hr} \mathrm{L} / \mathrm{d}$ followed by $12 \mathrm{hr} \mathrm{L} / \mathrm{d}$. Total dead embryonic mortality were decreased with increasing photoperiods. Narahari et al. (2002) found that quail breeders exposed to $24 \mathrm{hrs}$ continuous lighting significantly $(\mathrm{P}<0.05)$ exceeded in fertility percentage than those exposed to $12 \mathrm{hrs}$ lighting period. In contrast, El-Matary (1994) found insignificant effect, due to using 12 or $24 \mathrm{hrs}$ daily light on fertility percentage in Japanese quail. On the other hand, increasing hatchability with increasing photoperiod are in agreement with El-Matary (1994) who found that hatchability percentage was increased under long day light compared to short day light. In relation to sex ratio, the results of this experiment nearly in agreement with results obtained by Sreenivasaiah and Ramappa (1985) who reported that fertility of eggs were significantly higher for mating ratio of 1:1 than 1:2 and 1:3 in Japanese quail. However, Darwish et al. (1997) found that fertility of Japanese quail declined by $7.73 \%$ with decreasing sex ratio from $1: 2$ to $1: 6$ ). Moreover, Deeming and Wadland (2002) found that fertility and hatchability percent increased in sex ratio 1:8 compared to 1:12 in pheasants (Phasianus colchinus). In contrast, Mandour and Sharaf (1993) reported that there were no significant differences in fertility percent among different sex ratio $1: 1,1: 2,1: 3$ and 1:4 in Japanese quail.

Table 3. Fertility, hatchability and total dead embryo percent as affected by photoperiods and sex ratio at overall of age

\begin{tabular}{|c|c|c|c|c|}
\hline \multirow{2}{*}{\multicolumn{2}{|c|}{ Main effect }} & \multicolumn{3}{|c|}{ Traits } \\
\hline & & $\begin{array}{l}\text { Fertility } \\
\text { (F) } \%\end{array}$ & $\begin{array}{c}\text { Hatchability } \\
\text { (H)\% }\end{array}$ & $\begin{array}{c}\text { Total dead embryo } \\
\text { (TDE) } \%\end{array}$ \\
\hline \multirow{4}{*}{$\begin{array}{c}\text { Photoperiods } \\
\text { (P) }\end{array}$} & 12 & $95.86 \pm 0.89^{\mathrm{a}}$ & $66.56 \pm 2.32^{b}$ & $33.47 \pm 2.32^{\mathrm{a}}$ \\
\hline & 14 & $96.47 \pm 0.89^{\mathrm{a}}$ & $68.17 \pm 2.32^{b}$ & $31.81 \pm 2.32^{\mathrm{a}}$ \\
\hline & 16 & $95.92 \pm 0.89^{\mathrm{a}}$ & $75.83 \pm 2.32^{\mathrm{a}}$ & $24.14 \pm 2.32^{b}$ \\
\hline & 18 & $90.14 \pm 0.89^{b}$ & $76.39 \pm 2.32^{\mathrm{a}}$ & $23.58 \pm 2.32^{b}$ \\
\hline Significance of & fect $^{1}$ & $* * *$ & $* *$ & $* *$ \\
\hline \multirow{4}{*}{$\begin{array}{l}\text { Sex ratio } \\
\text { (SR) }\end{array}$} & $1: 2$ & $96.89 \pm 0.89^{\mathrm{a}}$ & $70.92 \pm 2.32$ & $29.11 \pm 2.32$ \\
\hline & $1: 4$ & $96.75 \pm 0.89^{\mathrm{a}}$ & $75.83 \pm 2.32$ & $24.08 \pm 2.32$ \\
\hline & $1: 6$ & $95.25 \pm 0.89^{\mathrm{a}}$ & $67.72 \pm 2.32$ & $32.28 \pm 2.32$ \\
\hline & $1: 8$ & $89.50 \pm 0.89^{b}$ & $72.47 \pm 2.32$ & $27.53 \pm 2.32$ \\
\hline \multicolumn{2}{|c|}{ Significance of effect } & $* * *$ & NS & NS \\
\hline \multicolumn{2}{|c|}{ Interaction (PxSR) } & $* * *$ & $\mathrm{NS}$ & NS \\
\hline
\end{tabular}

\section{Egg quality traits:}

Significant $(\mathrm{P}<0.05)$ differences were only found among photoperiod groups in egg shape index, yolk index and internal quality unit (Table 4). Eggs laid from hens kept under $16 \mathrm{hr} \mathrm{L} / \mathrm{d}$ had the highest egg shape index, while, the lowest value was obtained under $14 \mathrm{hr} \mathrm{L} / \mathrm{d}$. However, yolk index increased with increasing photoperiod, the highest value was obtained in eggs laid from birds subjected under $18 \mathrm{hr} \mathrm{L/d}$. In contrast, internal quality unit decreased with increasing photoperiod, the lowest value 
was obtained in eggs laid from birds subjected under $18 \mathrm{hr} \mathrm{L} / \mathrm{d}$. Increase of yolk index and decrease of internal quality unit may be returned to stimulus of photoperiod to increase in egg production. With increasing egg production yolk weight and diameter will be increased, and albumen viscosity will be decreased. Shell thickness increased with increasing photoperiods but without significant effect, these results are in agreement with El-Matary (1994) who reported that, shell thickness increased under long day photoperiod compared to short day photoperiod.

Table 4. Egg quality traits as affected by photoperiods and sex ratio at overall of age

\begin{tabular}{|c|c|c|c|c|c|}
\hline & & & Param & eters & \\
\hline Main eff & & $\begin{array}{l}\text { Egg shape } \\
\text { Index } \\
\text { (ESI) }\end{array}$ & $\begin{array}{l}\text { Yolk index } \\
\text { (YI) }\end{array}$ & $\begin{array}{c}\text { Internal } \\
\text { quality unit } \\
\text { (IQU) }\end{array}$ & $\begin{array}{c}\text { Shell } \\
\text { thickness } \\
\text { (STH) }\end{array}$ \\
\hline & 12 & $77.93 \pm 0.29^{\mathrm{ab}}$ & $47.57 \pm 0.31^{c}$ & $95.38 \pm 0.40^{\mathrm{a}}$ & $19.20 \pm 0.18$ \\
\hline Photoperiods & 14 & $77.19 \pm 0.27^{\mathrm{b}}$ & $48.23 \pm 0.29^{\mathrm{bc}}$ & $94.34 \pm 0.37^{\mathrm{ab}}$ & $19.35 \pm 0.17$ \\
\hline & 16 & $78.34 \pm 0.29^{\mathrm{a}}$ & $48.73 \pm 0.30^{\mathrm{ab}}$ & $92.68 \pm 0.40^{\mathrm{c}}$ & $19.27 \pm 0.18$ \\
\hline & 18 & $77.97 \pm 0.31^{\mathrm{ab}}$ & $49.11 \pm 0.32^{\mathrm{a}}$ & $93.99 \pm 0.43^{\mathrm{d}}$ & $19.66 \pm 0.19$ \\
\hline Significance of & $\operatorname{ect}^{1}$ & $*$ & $* *$ & $* * *$ & NS \\
\hline & $1: 2$ & $77.77 \pm 0.30$ & $48.94 \pm 0.31$ & $93.79 \pm 0.41$ & $19.42 \pm 0.19$ \\
\hline Sex ratio & $1: 4$ & $77.48 \pm 0.28$ & $48.43 \pm 0.29$ & $93.95 \pm 0.38$ & $19.42 \pm 0.17$ \\
\hline (SR) & $1: 6$ & $77.94 \pm 0.30$ & $48.36 \pm 0.32$ & $94.04 \pm 0.42$ & $19.37 \pm 0.19$ \\
\hline & $1: 8$ & $77.74 \pm 0.29$ & $47.92 \pm 0.30$ & $94.60 \pm 0.39$ & $19.27 \pm 0.18$ \\
\hline Significance of & ect & $\mathrm{NS}$ & NS & NS & $\mathrm{NS}$ \\
\hline Interaction (Px & & NS & NS & NS & NS \\
\hline
\end{tabular}

\section{Plumage conditions scores:}

Significant differences $(\mathrm{P}<0.05)$ were found among photoperiods, sex ratio and their interactions at all studied ages and entire experimental periods (Table 5). The highest score of plumage conditions was detected under $16 \mathrm{hr} \mathrm{L} / \mathrm{d}$ in sex ratio 1:2, while the lowest value was obtained under $18 \mathrm{hr}$ L/d with sex ratio 1:6 during 10, 18 and entire experimental period. In general, the trend of the plumage condition scores tended to decrease with decreasing sex ratio. This result indicated that, photoperiods and sex ratio show effect on behavioral activity of birds. Increasing photoperiods and sex ratio leads to increase plumage condition scores (increase plumage damage) than the other groups. The plumage damage might be mainly attributed to higher aggressive activity of birds under long day photoperiod and increase number males to females. 
Table 5. Plumage conditions (scores) ${ }^{1}$ of quails as affected by photoperiods and sex ratio

\begin{tabular}{|c|c|c|c|c|c|c|}
\hline \multirow{2}{*}{\multicolumn{2}{|c|}{ Main effect }} & \multicolumn{5}{|c|}{ Age (wks) } \\
\hline & & 8 & 10 & 14 & 18 & Overall \\
\hline \multirow{4}{*}{$\begin{array}{c}\text { Photoperiod } \\
\text { (P) }\end{array}$} & 12 & $3.84 \pm 0.12^{\mathrm{a}}$ & $4.34 \pm 0.15^{b}$ & $6.13 \pm 0.22^{\mathrm{a}}$ & $6.69 \pm 0.31^{b}$ & $5.38 \pm 0.11$ \\
\hline & 14 & $3.32 \pm 0.12^{\mathrm{b}}$ & $4.45 \pm 0.15^{\mathrm{b}}$ & $5.71 \pm 0.22^{\mathrm{b}}$ & $6.92 \pm 0.31^{\mathrm{b}}$ & $5.24 \pm 0.11$ \\
\hline & 16 & $3.90 \pm 0.12^{\mathrm{a}}$ & $4.97 \pm 0.15^{\mathrm{a}}$ & $5.90 \pm 0.22^{\mathrm{a}}$ & $7.80 \pm 0.31^{\mathrm{a}}$ & $5.74 \pm 0.11$ \\
\hline & 18 & $3.47 \pm 0.13^{\mathrm{b}}$ & $3.89 \pm 0.15^{\mathrm{c}}$ & $5.40 \pm 0.22^{\mathrm{b}}$ & $7.36 \pm 0.31^{\mathrm{a}}$ & $5.17 \pm 0.11$ \\
\hline \multicolumn{2}{|l|}{$\begin{array}{l}\text { Significance of } \\
\text { effect }^{2}\end{array}$} & $* *$ & $* * *$ & $*$ & $*$ & NS \\
\hline \multirow{4}{*}{$\begin{array}{l}\text { Sex ratio } \\
\quad(\mathrm{SR})\end{array}$} & $1: 2$ & $3.71 \pm 0.10^{\mathrm{a}}$ & $5.02 \pm 0.12^{\mathrm{a}}$ & $7.84 \pm 0.18^{\mathrm{a}}$ & $9.61 \pm 0.25^{\mathrm{a}}$ & $6.67 \pm 0.93^{A}$ \\
\hline & $1: 4$ & $3.68 \pm 0.12^{\mathrm{a}}$ & $4.33 \pm 0.14^{b}$ & $5.72 \pm 0.21^{\mathrm{b}}$ & $7.01 \pm 0.29^{b}$ & $5.30 \pm 0.11^{\mathrm{B}}$ \\
\hline & $1: 6$ & $3.35 \pm 0.13^{b}$ & $4.34 \pm 0.15^{\mathrm{b}}$ & $4.92 \pm 0.23^{c}$ & $5.63 \pm 0.32^{\mathrm{c}}$ & $4.84 \pm 0.12^{\mathrm{C}}$ \\
\hline & $1: 8$ & $3.29 \pm 0.15^{\mathrm{b}}$ & $3.96 \pm 0.17^{\mathrm{c}}$ & $4.68 \pm 0.26^{\mathrm{c}}$ & $6.42 \pm 0.36^{\mathrm{c}}$ & $4.72 \pm 0.13^{C}$ \\
\hline \multicolumn{2}{|l|}{$\begin{array}{l}\text { Significance of } \\
\text { effect }\end{array}$} & $*$ & $* * *$ & $* * *$ & $*$ & $*$ \\
\hline \multicolumn{2}{|l|}{$\begin{array}{l}\text { Interaction } \\
\text { (PxSR) }\end{array}$} & $* * *$ & $* * *$ & $* * *$ & $*$ & $*$ \\
\hline \multicolumn{7}{|c|}{ 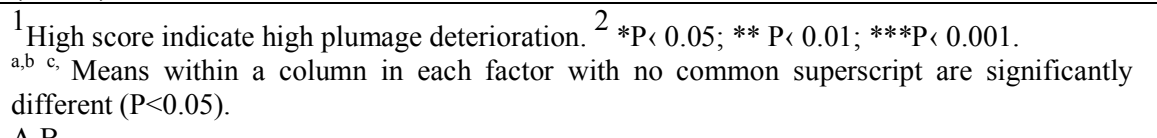 } \\
\hline
\end{tabular}

\section{The area of the cloacal gland $\left(\mathrm{mm}^{2}\right)$ :}

Significant differences $(\mathrm{P}<0.05)$ were found among photoperiods groups at 8,10 and 18 weeks of age and during the entire experimental period from 8 to 18 weeks of age (Table 6). Cloacal gland area increased with increasing daily photoperiods, the highest value was detected in males kept under $18 \mathrm{hr} \mathrm{L} / \mathrm{d}$, while the lowest area was recorded in males kept under $12 \mathrm{hr} \mathrm{L} / \mathrm{d}$ during 8,10 and 18 weeks of age and the entire experimental period. On the other hand, there are significant $(\mathrm{P}<0.05)$ differences among sex ratio groups at 10 weeks of age. The highest value was obtained in sex ratio 1:4, while the lowest value was obtained in sex ratio 1:8.

Sachs (1967) and Siopes and Wilson (1975) reported that the area of the cloacal gland is a good indicator of testicular size and function. Increasing in cloacal gland area in males subjected to long photoperiods (18hr) than short photoperiods (12hr), may be due to that photoperiods play an important role in development of gonads in male quails. Photoperiods stimulate the hypothalamus area via eyes and extra-retinal photoreceptors to produce GnRH, FSH and LH. It is well know that in males, LH controls the production of the major sex steroid (testosterone) that is responsible for increasing size and area of cloacal gland (Bacon et al., 1980; Dunn and Sharp, 1990 and Lewis et al., 1999). 
Table 6. The area of cloacal gland $\left(\mathrm{mm}^{2}\right)$ of males as affected by photoperiods and sex ratio

\begin{tabular}{|c|c|c|c|c|c|c|}
\hline \multirow{2}{*}{\multicolumn{2}{|c|}{ Main effect }} & \multicolumn{5}{|c|}{ Age (wks) } \\
\hline & & 8 & 10 & 14 & 18 & Overall \\
\hline \multirow{4}{*}{$\begin{array}{c}\text { Photoperiods } \\
\text { (P) }\end{array}$} & 12 & $338.27^{\mathrm{b}}$ & $321.29^{c}$ & 441.95 & $466.93^{b}$ & $392.15^{\mathrm{c}}$ \\
\hline & 14 & $415.77^{\mathrm{a}}$ & $430.44^{b}$ & 500.09 & $493.58^{\mathrm{ab}}$ & $460.19^{b}$ \\
\hline & 16 & $416.63^{\mathrm{a}}$ & $435.56^{b}$ & 448.01 & $501.66^{\mathrm{ab}}$ & $450.61^{b}$ \\
\hline & 18 & $460.28^{\mathrm{a}}$ & $509.81^{\mathrm{a}}$ & 457.66 & $520.43^{\mathrm{a}}$ & $487.16^{\mathrm{a}}$ \\
\hline SEM & & 16.51 & 25.41 & 21.69 & 19.97 & 10.86 \\
\hline Significance of & fect $^{1}$ & $* * *$ & $* * *$ & $\mathrm{NS}$ & $*$ & $* *$ \\
\hline \multirow{4}{*}{$\begin{array}{l}\text { Sex ratio } \\
\quad(\mathrm{SR})\end{array}$} & $1: 2$ & 415.15 & $422.21^{\mathrm{ab}}$ & 465.12 & 515.15 & 454.56 \\
\hline & $1: 4$ & 391.60 & $470.15^{\mathrm{a}}$ & 458.20 & 468.55 & 447.15 \\
\hline & 1:6 & 402.87 & $445.50^{\mathrm{a}}$ & 486.06 & 503.75 & 459.75 \\
\hline & $1: 8$ & 421.33 & $359.25^{\mathrm{b}}$ & 438.33 & 495.16 & 428.66 \\
\hline SEM & & 19.25 & 22.34 & 22.45 & 21.64 & 10.36 \\
\hline \multicolumn{2}{|c|}{ Significance of effect } & NS & $*$ & NS & NS & NS \\
\hline \multicolumn{2}{|c|}{ Interaction (PxSR) } & NS & NS & NS & NS & $\mathrm{NS}$ \\
\hline
\end{tabular}

\section{Blood parameters}

High significant differences $(\mathrm{P}<0.01)$ were found among photoperiods, sex ratio, sex and their interactions on all plasma elements (Table 8). Plasma concentration of both calcium and inorganic phosphorus increased with increasing photoperiod. The lowest value was obtained in birds kept under $12 \mathrm{hr} \mathrm{L} / \mathrm{d}$ but the highest value was obtained in birds kept under $18 \mathrm{hr} \mathrm{L} / \mathrm{d}$ irrespective of sex ratio and sex. This increment may be returned to either; increase period of feeding or increase of reproductive and metabolic hormones (Lewis et al., 1996 and Boon et al., 2000).

On the other hand, iron ion was fluctuated among different photoperiods where birds kept under 14 and $18 \mathrm{hr} \mathrm{L} / \mathrm{d}$ had superior values than in those kept under 12 and $16 \mathrm{hr} \mathrm{L} / \mathrm{d}$. In relation to sex ratio, inorganic phosphorus increased with increase of sex ratio, the lowest value was obtained in birds kept under $12 \mathrm{hr} \mathrm{L} / \mathrm{d}$ but the highest value was obtained in birds kept under $18 \mathrm{hr} \mathrm{L} / \mathrm{d}$ irrespective of photoperiods and sex. Moreover, calcium and iron were fluctuated among different sex ratio, the lowest value of calcium was obtained in birds kept under 1:6 but the highest value was obtained in birds kept under 1:8, and the lowest value of iron was obtained in birds kept under 1:8 but the highest value was obtained in birds kept under 1:6. In this respect, females had significantly higher $(\mathrm{P}<0.01)$ calcium and inorganic phosphorus, but significantly lower $(\mathrm{P}<0.01)$ iron than males irrespective of photoperiods and sex ratio (Table 7).

Tsang et al. (1988) stated that calcium plays an important role in conversion of estradiol-17 $\beta$-3-sulfate to estradiol-17 $\alpha$-3-sulfate. Moreover, Ahmad et al. (1990) reported that administration of oral calcium to female animals led to higher increase serum level of FSH leading to increased rate of ovulation. Brunette and Leclerc 
(2001) found that estrogen by itself regulates electrolyte reabsorption by the distal tubule luminal membrane. Nordin et al. (1991\&1994); Adami et al. (1992); McKane et al. (1995); Heshemati et al. (1998) suggested that estrogen enhances $\mathrm{Ca}^{++}$ion reabsorption by stimulating parathyroid hormone (PTH) secretion and activation of vitamin D which have played an important role to increase calcium intestinal absorption, more efficient renal calcium reabsorption and inhibition of bone reabsorption by PTH (Gill and Christakos, 1995 and Karen and Rosenthal, 2006).

Table 7. Plasma concentration of calcium, inorganic phosphorus and iron ions of male and female at 18 weeks of age

\begin{tabular}{lccc}
\hline & Male & Female & $\begin{array}{c}\text { Significance of } \\
\text { effect }^{1}\end{array}$ \\
\hline Calcium (mg/L) & $52.78 \pm 3.13^{\mathrm{b}}$ & $110.68 \pm 3.16^{\mathrm{a}}$ & $* * *$ \\
$\begin{array}{l}\text { Inorganic phosphorus } \\
(\mathbf{m g} / \mathbf{L})\end{array}$ & $33.19 \pm 1.65^{\mathrm{b}}$ & $63.53 \pm 1.37^{\mathrm{a}}$ & $* * *$ \\
Iron $(\mathbf{m g} / \mathbf{L})$ & $2.11 \pm 0.06^{\mathrm{a}}$ & $1.86 \pm 0.04^{\mathrm{b}}$ & $* *$ \\
\hline $1 * \mathrm{P}<0.05 ; * * \mathrm{P}<0.01 ; * * * \mathrm{P}<0.001$ & &
\end{tabular}

$1 * \mathrm{P}<0.05 ; * * \mathrm{P}<0.01 ; * * * \mathrm{P}<0.001$

${ }^{\mathrm{a}, \mathrm{b}}$ Means in a row with no common superscript differ $(\mathrm{P}<0.05)$.

Mortality rate:

Results showed significant $(\mathrm{P}<0.05)$ differences among photoperiods and sex ratios on average mortality rate of quails during the entire study period (Table 9). The lowest mortality rate was recorded in birds kept under $16 \mathrm{hr} \mathrm{L} / \mathrm{d}$, but the highest value was recorded in birds kept under $18 \mathrm{hr} \mathrm{L} / \mathrm{d}$ irrespective of sex ratio and sex. Also, sex ratio had affected total mortality rate. The lowest mortality rate was recorded at sex ratio 1:6, but the highest value was recorded at sex ratio 1:8 irrespective of photoperiods and sex.

From this experiment, it could be concluded that, photoperiods $16 \mathrm{hr} \mathrm{L} / \mathrm{d}$ and sex ratio 1:4 were significantly better in most studied traits compared with other experimental groups. The best interaction between photoperiods and sex ratio was obtained in $16 \mathrm{hr} \mathrm{L/d}$ at 1:4 sex ratio to increase Japanese quail breeder's performance under commercial production.

Table 9. Total mortality rate of quails as affected by photoperiods and sex ratio from 6 to 18 weeks of age

\begin{tabular}{ccccccccc}
\hline & \multicolumn{3}{c}{ Photoperiods (hr/d) } & \multicolumn{3}{c}{ Sex ratio (male: female) } \\
\cline { 2 - 8 } & $\mathbf{1 2}$ & $\mathbf{1 4}$ & $\mathbf{1 6}$ & $\mathbf{1 8}$ & $\mathbf{1 : 2}$ & $\mathbf{1 : 4}$ & $\mathbf{1 : 6}$ & $\mathbf{1 : 8}$ \\
\hline$\%$ & $4.60^{\mathrm{b}}$ & $4.30^{\mathrm{b}}$ & $1.80^{\mathrm{c}}$ & $6.14^{\mathrm{a}}$ & $2.08^{\mathrm{b}}$ & $2.08^{\mathrm{b}}$ & $1.34^{\mathrm{b}}$ & $5.56^{\mathrm{a}}$ \\
\hline
\end{tabular}

$\mathrm{a}, \mathrm{b}$ Means in a row in each factor with no common superscript differ $(\mathrm{P}<0.05)$. 


\section{REFERENCES}

Abou-Kaseem D. E., 2006. A study on some factors influencing egg production and incubation in quail. M.Sc. Thesis. Faculty of Agriculture. Zagazig University. Egypt.

Adami S., D. Gatti, F. Bertoldo, M. Rossini, A. Fratta-Pasini, N. Zamberian, E. Facci and V. Lo-Cascio, 1992. The effects of menopause and estrogen replacement therapy on the renal handling of calcium. Osteoporosis International (2) 180-185.

Ahmad M. R., M. E. Mamdouh, M. I. Tarek and M. E. Amal, 1990. Effect of Calcium on Estrogen and Follicle Stimulating Hormone Secretion in Rabbits. Arch. Pharm. Res. 13 (4) 379-381.

Ahmed A. M. H., M. F. Ali, H. E. Ayoub, and Y. M. El-Hommosany, 2000. Photoperiodsic control of laying performance in female Japanese quail. Egypt Poult. Sci. Vol. 20:603-615.

Bacon W. L., K. I. Brown and M. A. Musser, 1980. Changes in plasma calcium, phosphorus, lipids and estrogens in turkey hens with reproductive state. Poult. Sci. 59:444-452.

Bates D.P., L. E. Hanson, M. E. Cook, B. C. Wentworth, M. L. Sunde and J. J. Bitgood, 1987. Lighting and sex ratio for breeding ring necked pheasants in confined housing. Poult. Sci. 66 (4): 605-612.

Boon P. G., V. Henk and D. Serge, 2000. Effect of photoperiods on body weight gain, and daily intake and energy expending in Japanese quail (Coturnix c. japonica). Physiol. Behave. 70: 249-260.

Brunette M. G. and M. Leclerc, 2001. Effect of estrogen on calcium and sodium transport by the nephron luminal membranes. J. Endocrinol. 170: 441-450.

Çetin O., 2002. Egg production and some hatchability characteristics of Rock Partridges (Alectoris graeca) mated at different rates. Turk J. Vet. Anim. Sci. 26:1009-1011.

Chaturvedi C., A. Meier and R. Bhatt, 1991. Effect of $12 \mathrm{hr}$ temporal relation of serotonin and dopamine precursor drugs (5-HTP and L-DOPA) on photo sexual responses of immature Japanese quail. Indian, J. Exp. Biol. Apr. 29(4): 342-345.

Darwish A. A., A. A. Faten Ibrahim and S. M. T. EL-Tantawy, 1997. Effects of sex ratio, housing system, egg size and shell colour on hatching performance of Japanese quail. Second Hungarian Egyptian poultry conference 16-19September. Godollo, Hungary. 283-293.

Deeming D. C. and D. Wadland, 2002. Influence of mating sex ratio in ommercial pheasant flocks on bird health and the production, fertility, and hatchability of eggs. Bri. Poult. Sci. Vol. 43: 16-23.

Dunn I. C. and P. J. Sharp, 1990. Photoperiodsic requirements for LH release in juvenile broiler and egg-laying strains of domestic chickens fed adlibtum or restricted diets. J. Repord. Fertil. 90: 329-335.

El-Fiky F.A., M.M. Mabrouk, M. A. Aboul-Hassan and N. A. Abdel-Mounsef, 2006. Effect of sex ratio on some productive and reproductive traits in Japanese quail. Egypt Poult. Sci.Vol. (26) (II): 647-662.

El-Matary I.F.A., 1994. Effect of lighting regime and feeding system on the productive and reproductive performance of the quail. Msc. Thesis. Fac. of Agric. Al-Azhar Univ., Egypt. 
El-Nagar A. Samar, H. S. Zeweil, A. A. Mansour Basma, 2007. Relationship between thyroid gland hormones and reproductive functions in Japanese quail kept under different systems of photoperiods. Egypt Poult. Sci. (27) 281-308.

Farner D. S., 1964. The photoperiodsic control of reproductive cycle in birds. Am., Scientist, 52:137-156.

Gerken M., 1991. Antagonistic relationship between behavioural and production traits in poultry. Habilitation. Thesis, Science of Animal, Bonn Uni., Germany.

Gill R. K. and S. Christakos, 1995. Regulation by estrogen through the 5 flanking region of the mouse calbindin D 28K gene. Mole. Endocrinol. 9: 319-326.

Heshemati H. M., S. Khosla, M. F. Burritt, W. M. O'Fallon and B. L. Riggs, 1998. A defect in renal calcium conservation may contribute to the pathogenesis of postmenopausal osteoporosis. J. Clin. Endocrinol. Metab. (83) 1916-1920.

Ivar J. and R. Jan, 1968. Genetics and Animal Breeding. Oliver \& Boyd, Ltd, Edinburh.

Karen L. and D. V. Rosenthal, 2006. Calcium Metabolism In Rabbits: What's New? The North American Veterinary Conference, 1764-1765.

Khalil H.A., 2004. Productive and reproductive aspects of Japanese quail (Coturnix coturnix japonica) under heat stress conditions. Ph. D. Thesis, Faculty of Agriculture, Suez Canal, University, Ismailia, Egypt.

Khalil H.A., M. Hassanein, M. E., Mady and M. Gerken, 2006. Effect of housing conditions on performance of Japanese quail (Coturnix coturnix japonica) under cold stress in winter. Egypt J. Anim. Prod. 43(1): 71-82.

Khalil H.A., M. Hassanein, M. E., Mady and M. Gerken, 2008. Effects of thermal conditioning during hatching and early growth on heat tolerance of Japanese quail. Egypt J. Anim. Prod. 45(1): 55-69.

Kondaiah N., B. Panda and R. Singhal, 1983. Internal egg measure for quail egg. Indian J. Anim. Sci. (11): 1261-1264.

Lewis P. D., G. C. Perry, T. R. Morris and J. A. Douthwaite, 1999. Effect of timing and size of photoperiods change on plasma FSH concentration and the correlation between FSH and age at first egg in pullets. Br. Poult. Sci. 59: 444- 452.

Lewis P.D., G. C. Perry and T. R. Morris, 1996. Effect of 5 hour increases in photoperiod and in feeding opportunity on age at first egg. Br. Poult. Sci. 37 (1) $15-19$.

Mandour M. A. and M. M. Sharaf, 1993. Influence of age, mating ratio and crossing on hatching performance of Japanese quail (Coturnix c. japonica) eggs. Egypt. Poult Sci. (13): 393-409.

McKane W. R., S. Khosla, M. F. Burritt, P. C. Kao, D. M. Wilson, S. J. Ory and B. L. Riggs, 1995. Mechanism of renal calcium conservation with estrogen replacement therapy in women in early post menopause. A clinical research center study. J. Clini. Endocrinol. Met. 80: 3458-3464.

National Research Council, 1994. Nutrient Requirements of Poultry. 9th rev. ed. National Academy Press, Washington, DC.

Nordin B. E., A. G. Need, H. A. Morris, M. Horowitz and W. A. Robertson, 1991. Evidence for a renal calcium leak in post menopausal women. J. Clini. Endocrinol. Meta. 72: 401-407.

Nordin B. E., M. Horowitz, A. Need and H. A. Morris, 1994. Renal leak of calcium in post-menopausal osteoporosis. Clini. Endocrinol. 41: 41-45. 
Prabakaran R., K. A. Mujeer, M. Ahmed, A. Thangavel and V. Sundararasu, 1991b. Effect of photoperiods on the laying performance of Japanese quails. J. Vet. And Anim. Sci. 22: 5-8.

SAS Institute, 1998. SAS statistical guide for personal computer, SAS Institute Inc. Cary, NC.

Sachs B.D., 1967. Photoperiodsic control of the cloacal gland of the Japanese quail. Science 157: 201-203.

Sakurai H., 1983. Influence of ambient temperature and wind velocity on egg production of japanese quails. Japanese poultry Sci. 20 (2): 80-86.

Sharp P.F., 1929. U. S. Egg Poultry Mag. 35(6): 14-17.

Siopes T.D. and W.O. Wilson, 1975. The cloacal gland- an external indicator of testicular development in coturnix. Poultry Sci. 54: 1225-1229.

Sreenivasaiah P. V. and B. S. Ramappa, 1985. Influence of mating ratios and preincubation storage on fertility and hatchability of Japanese quail eggs (Coturnix coturnix Japonica). World Rev. Anim. Prod. 21(4, 3, 5): 25-28.

Tsang C.P., A.A. Grunder, H. Soares and R. Narbaitz, 1988. Effects of cholecalciferol or calcium deficiency on oestrogen metabolism in the laying hen Br. Poult. Sci. 29 (4) 753-759.

Tsuyoshi H. and M. Wada, 1992. Termination of LH secretion in Japanese quail due to high-and low-temperature cycles and short daily photoperiods. Gen. Comp Endocrinol. Mar. 85(5): 424-429.

Wada M., 1993. Low temperature and short days together induce thyroid activation and suppression of LH release in Japanese quail. Gen Comp Endocrinol. Jun. 90(3): 355-363. 
تأثير طول الفترة الضوئية والنسبة الجنسية على الأداء الانتاجى والتناسلى للسمان اليابانى حسن عبد الغفار خليل، أحمد محمد حنفى، محمد رشدى إسماعيل، محمد السيد ماضى

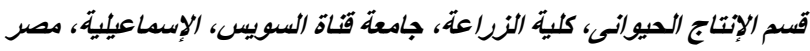

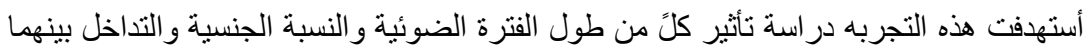

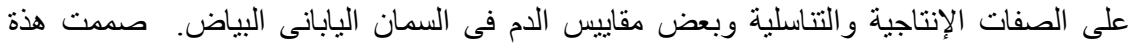

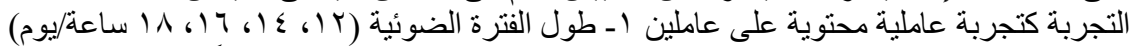

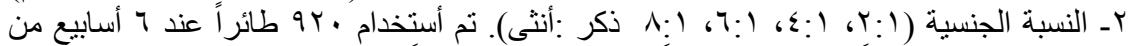

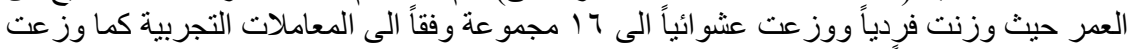

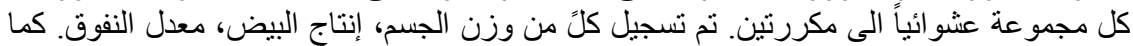

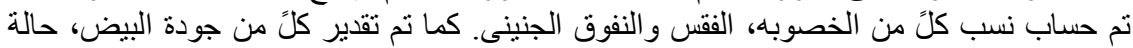

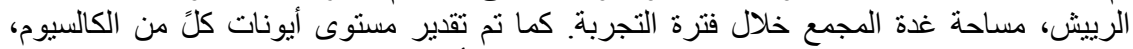

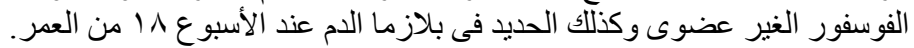

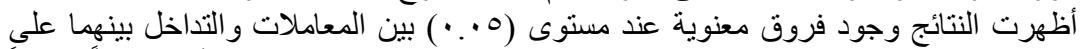

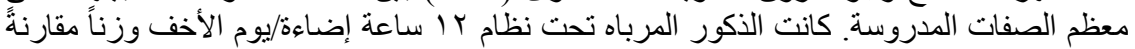

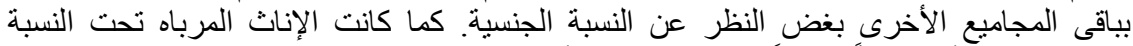

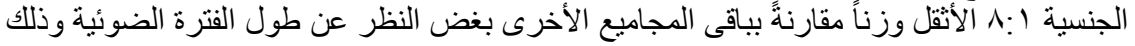

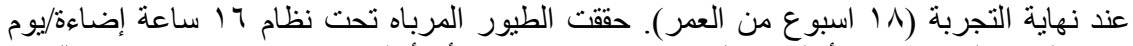

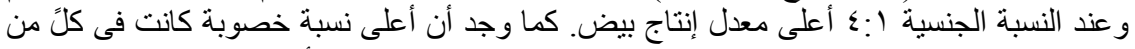

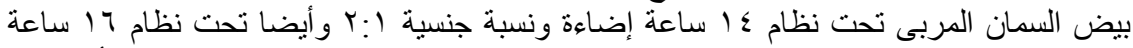

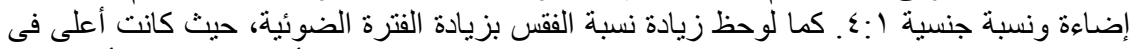

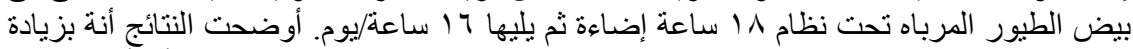

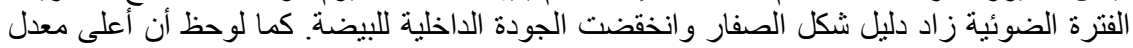

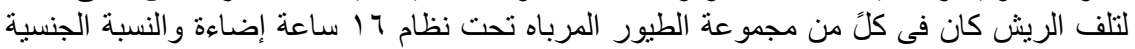

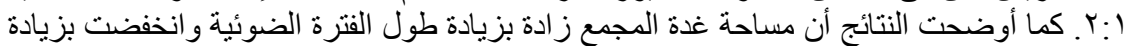

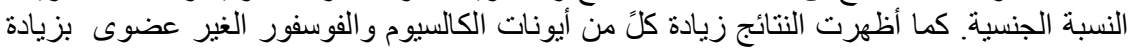

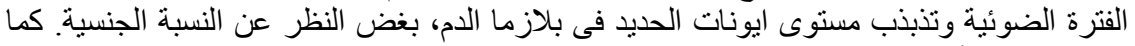

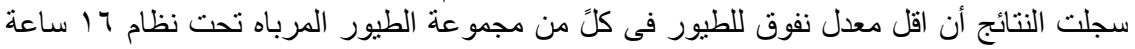

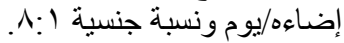

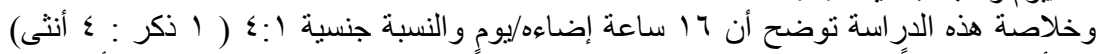

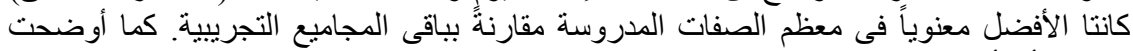

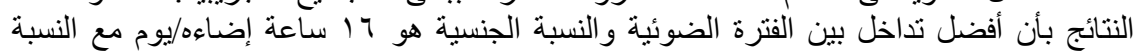
الجنسية (:؛ للحصول على أعلى أداء للسمان اليابانى البياض تحت نظة لنام الإنتاج التجارى. 

Egyptian J. Anim. Prod. 48, Suppl. Issue, April (2011):295-309

Table 8. Plasma concentration of calcium, inorganic phosphorus and iron ions in quails as affected by photoperiods and sex ratio at 18 weeks of age Photoperiods (hr/d)

\begin{tabular}{|c|c|c|c|c|c|c|c|c|c|c|c|c|c|c|c|c|c|c|c|c|}
\hline & \multicolumn{4}{|c|}{12} & \multicolumn{4}{|c|}{14} & \multicolumn{4}{|c|}{16} & \multicolumn{4}{|c|}{18} & \multirow{2}{*}{\multicolumn{4}{|c|}{$\begin{array}{c}\text { Sex ratio } \\
\text { (male: female) }\end{array}$}} \\
\hline & \multicolumn{4}{|c|}{$\begin{array}{c}\text { Sex ratio } \\
\text { (male: female) }\end{array}$} & \multicolumn{4}{|c|}{$\begin{array}{c}\text { Sex ratio } \\
\text { (male: female) }\end{array}$} & \multicolumn{4}{|c|}{$\begin{array}{c}\text { Sex ratio } \\
\text { (male: female) }\end{array}$} & \multicolumn{4}{|c|}{$\begin{array}{c}\text { Sex ratio } \\
\text { (male: female) }\end{array}$} & & & & \\
\hline & $1: 2$ & $1: 4$ & $1: 6$ & $1: 8$ & $1: 2$ & $1: 4$ & $1: 6$ & $1: 8$ & $1: 2$ & $1: 4$ & $1: 6$ & $1: 8$ & $1: 2$ & $1: 4$ & $1: 6$ & $1: 8$ & $1: 2$ & $1: 4$ & $1: 6$ & $1: 8$ \\
\hline $\begin{array}{c}\text { Calcium } \\
(\mathrm{mg} / \mathrm{L}) \\
\text { SEM=8.20 } \\
\end{array}$ & $\begin{array}{c}43.7 \\
\mathrm{c}\end{array}$ & $\begin{array}{c}52.9 \\
\mathrm{c}\end{array}$ & $\begin{array}{c}70.2 \\
b c\end{array}$ & $\begin{array}{c}83.6 \\
a b\end{array}$ & $\begin{array}{c}68.7 \\
\mathrm{bc}\end{array}$ & $\begin{array}{c}94.3 \\
a b\end{array}$ & $\begin{array}{c}71.3 \\
b\end{array}$ & $\begin{array}{c}103.2 \\
\mathrm{a}\end{array}$ & $\begin{array}{c}83.3 \\
a b\end{array}$ & $\begin{array}{c}87.3 \\
a b\end{array}$ & $\begin{array}{c}82.2 \\
a b\end{array}$ & $\begin{array}{c}76.7 \\
b\end{array}$ & $\begin{array}{c}106.1 \\
\mathrm{a}\end{array}$ & $\begin{array}{c}99.8 \\
\mathrm{a}\end{array}$ & $\begin{array}{c}70.0 \\
\mathrm{bc}\end{array}$ & $\begin{array}{c}108.0 \\
\mathrm{a}\end{array}$ & \multirow[t]{2}{*}{$\begin{array}{c}75.8 \\
B\end{array}$} & \multirow[t]{2}{*}{$\begin{array}{c}83.6 \\
\mathrm{AB}\end{array}$} & \multirow[t]{2}{*}{$\begin{array}{c}73.4 \\
B\end{array}$} & \multirow[t]{2}{*}{$\frac{92.8}{\mathrm{~A}}$} \\
\hline Overall & \multicolumn{4}{|c|}{$62.58 \pm 9.24^{b}$} & \multicolumn{4}{|c|}{$84.31 \pm 10.23^{\mathrm{ab}}$} & \multicolumn{4}{|c|}{$82.56 \pm 10.37^{a b}$} & \multicolumn{4}{|c|}{$96.25 \pm 9.47^{\mathrm{a}}$} & & & & \\
\hline $\begin{array}{c}\text { Inorganic } \\
\text { Phosphorus } \\
(\mathrm{mg} / \mathrm{L}) \\
\text { SEM= 1.52 }\end{array}$ & $\begin{array}{c}29.2 \\
\mathrm{~cd}\end{array}$ & $\begin{array}{c}24.2 \\
\mathrm{~d}\end{array}$ & $\begin{array}{c}22.7 \\
d\end{array}$ & $\begin{array}{l}57.3 \\
\text { abcd }\end{array}$ & $\begin{array}{l}40.6 \\
\text { abcd }\end{array}$ & $\begin{array}{l}51.3 \\
\text { abcd }\end{array}$ & $\begin{array}{l}59.7 \\
\text { abcd }\end{array}$ & $\begin{array}{l}40.1 \\
\text { abcd }\end{array}$ & $\begin{array}{l}55.1 \\
\text { abcd }\end{array}$ & $\begin{array}{l}65.2 \\
\mathrm{abc}\end{array}$ & $\begin{array}{l}56.2 \\
\text { abcd }\end{array}$ & $\begin{array}{l}51.8 \\
\text { abcd }\end{array}$ & $\begin{array}{l}38.0 \\
\text { bed }\end{array}$ & $\begin{array}{l}56.9 \\
\text { abcd }\end{array}$ & $\begin{array}{l}73.0 \\
\mathrm{ab}\end{array}$ & $\begin{array}{c}77.3 \\
\mathrm{a}\end{array}$ & \multirow[t]{2}{*}{$\underset{B}{40.7}$} & \multirow[t]{2}{*}{$\begin{array}{l}49.0 \\
\mathrm{AB}\end{array}$} & \multirow[t]{2}{*}{52.9} & \multirow[t]{2}{*}{$\underset{\mathrm{A}}{57.7}$} \\
\hline Overall & \multicolumn{4}{|c|}{$33.41 \pm 5.48^{c}$} & \multicolumn{4}{|c|}{$48.17 \pm 4.67^{b c}$} & \multicolumn{4}{|c|}{$56.54 \pm 5.14^{\mathrm{ab}}$} & \multicolumn{4}{|c|}{$61.33 \pm 4.28^{\mathrm{a}}$} & & & & \\
\hline $\begin{array}{c}\text { Iron } \\
(\mathrm{mg} / \mathrm{L}) \\
\mathrm{SEM}=0.15\end{array}$ & $\begin{array}{l}1.7 \\
\mathrm{bc}\end{array}$ & $\begin{array}{l}2.1 \\
\mathrm{ab}\end{array}$ & $\begin{array}{l}2.1 \\
\mathrm{ab}\end{array}$ & $\begin{array}{c}1.3 \\
\mathrm{c}\end{array}$ & $\begin{array}{l}2.1 \\
\mathrm{ab}\end{array}$ & $\begin{array}{l}2.1 \\
\mathrm{ab}\end{array}$ & $\begin{array}{c}2.3 \\
\mathrm{a}\end{array}$ & $\begin{array}{l}2.0 \\
\mathrm{ab}\end{array}$ & $\begin{array}{c}1.3 \\
\mathrm{c}\end{array}$ & $\begin{array}{l}1.9 \\
\mathrm{abc}\end{array}$ & $\begin{array}{l}2.0 \\
\mathrm{ab}\end{array}$ & $\begin{array}{l}1.8 \\
\mathrm{abc}\end{array}$ & $\begin{array}{l}2.3 \\
\mathrm{ab}\end{array}$ & $\begin{array}{l}1.8 \\
\mathrm{abc}\end{array}$ & $\begin{array}{l}2.2 \\
\mathrm{ab}\end{array}$ & $\begin{array}{l}2.1 \\
\mathrm{ab}\end{array}$ & $\begin{array}{l}1.9 \\
\mathrm{AB}\end{array}$ & $\begin{array}{l}1.9 \\
\mathrm{AB}\end{array}$ & 2.1 & $\begin{array}{l}1.8 \\
\mathrm{~B}\end{array}$ \\
\hline Overall & \multicolumn{4}{|c|}{$1.83 \pm 0.09^{b}$} & \multicolumn{4}{|c|}{$2.19 \pm 0.08^{\mathrm{a}}$} & \multicolumn{4}{|c|}{$1.81 \pm 0.09^{b}$} & \multicolumn{4}{|c|}{$2.13 \pm 0.11^{\mathrm{a}}$} & & & & \\
\hline
\end{tabular}

Issued by The Egyptian Society of Animal Production 